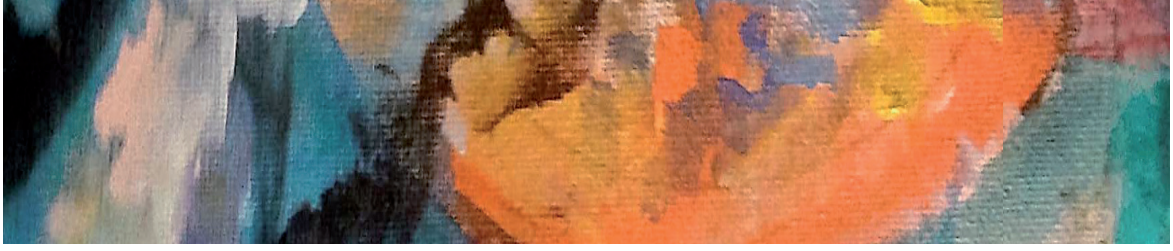

Entreculturas 11 (2021) pp. 105-119 - ISSN: 1989-5097

\title{
LA (IN)TRADUCIBILIDAD \\ DEL PROTOTEXTO AUDIOVISUAL: \\ EL COLOR EN HERO, DE ZHANG YIMOU
}

\section{The (In)Translatability of the Audiovisual Prototext: Colour in Hero, by Zhang Yimou}

\author{
(D) Lingzhi Nie \\ Universidad de Xiangtan \\ Recibido: 1 de abril de 2020 \\ Aceptado: 16 de junio de 2020 \\ Publicado: 27 de febrero de 2021
}

\begin{abstract}
The images and colours are an inherent part of cinema and are at the same time a narrative prototext that is usually assumed as a lingua franca in audiovisual translation (TAV). However, each linguistic community may decode this semiotic information differently depending on the present ideology in their language.

Zhang Yimou's movie Hero gives special importance of colours. Therefore, we make a comparison of the connotations of the colours black, red and blue to investigate whether the difference in the perception of colours causes asymmetries in the information received by the audience in the original and translated versions in this case. From the symbology and the connoted values of the colours, we'll discover that to what extent the translation is associated with a loss, addition or alteration of meaning, and how this process affects the reception of the film by the audience of the target language.
\end{abstract}

KEYWORDS: audiovisual translation (TAV), connoted value of colors, semiotic information, extralinguistic context.

\section{RESUMEN}

Las imágenes y los colores son una parte inherente del cine y constituyen al mismo tiempo un prototexto narrativo que se suele asumir como una lengua franca en traducción audiovisual (TAV). Sin embargo, cada comunidad lingüística puede descodificar de un modo diferente esta información semiótica en función de la ideología presente en su lengua.

En la película Hero de Zhang Yimou se da especial importancia a los colores. Por ello, realizamos una comparación de las connotaciones de los colores negro, rojo y azul para investigar si la diferencia en la percepción de dichos colores provoca asimetrías en la información que reciben los espectadores en la versión original y la traducida. A partir de la simbología y los valores connotados de los colores, valoramos hasta qué punto la traducción va asociada a una pérdida, adición o alteración del significado y en qué medida este proceso afecta a la recepción de la película por parte de los espectadores de la lengua meta.

PALABRAS CLAVE: traducción audiovisual (TAV), valor connotado de los colores, información semiótica, contexto extralingüístico. 


\section{LA (IN)TRADUCIBILIDAD DEL PROTOTEXTO AUDIOVISUAL}

\section{INTRODUCCIÓN}

La comprensión lingüística requiere captar tanto el significado de los signos de la lengua como el sentido del texto en su conjunto. Es decir, la comprensión de palabras, frases, oraciones y párrafos no puede producirse sin su contexto. El uso de las lenguas es inseparable de su entorno específico y concreto. Como señala Burad (2009: 6), el contexto puede ser lingüístico o extralingüístico.

El entorno lingüístico en que aparece una palabra se denomina contexto lingüístico. Los demás elementos no lingüísticos que preceden y siguen a un enunciado, e intervienen en la información transmitida de una manera indirecta, en vez de ser componentes lingüísticos, "son las circunstancias inmediatas que rodean la situación lingüística y que permiten entender el sentido concreto que le corresponde a un texto" (Burad, 2009: 6). Los agrupamos como contexto extralingüístico.

En el ámbito audiovisual, todos los elementos visuales y auditivos, tales como actuaciones, escenas, colores, músicas, sonidos, prendas, etc., pertenecen al contexto extralingüístico. Tal y como resume Chaume Varela (2013: 13-14):

\begin{abstract}
(...) la traducción audiovisual (TAV) es la denominación con la que los círculos académicos se refieren a las transferencias semióticas, interlingüísticas e intralingüísticas entre textos audiovisuales, tanto a las más consolidadas, como el doblaje y la subtitulación, como a las más novedosas, como el rehablado o la audiosubtitulación.
\end{abstract}

A la vez que permiten gozar de la belleza a los espectadores y satisfacer la necesidad para producir una sensación más realista e intensa, influyen en la comprensión y apreciación de la película.

Como un intermediario especial, las obras audiovisuales se limitan más en el contexto situacional y el contexto cultural. Las informaciones no solo se transmiten mediante el contexto lingüístico, sino también a través del sentido auditivo y visual. Es decir, no podemos ignorar el papel que juega el contexto extralingüístico en la TAV.

Los colores, como parte muy importante entre los elementos extralingüísticos, desempeñan un papel indispen- sable. No solo se enriquecen las imágenes para que sean más atractivas, sino que muchas veces también transmiten información: o refuerzan el ambiente y ayudan a los espectadores en la comprensión, o transmiten indirectamente las ideas o intención del director.

Muchas veces los colores tienen significados concretos y definitivos en las obras audiovisuales e incluso funcionan como una lengua franca para que los espectadores de diferentes zonas o países capten la misma información en las películas, y no suelen traducirse. Es de presuponer que todo el mundo entiende el color del mismo modo. No obstante, como demuestran los ejemplos concretos en este artículo, por la diferencia de cultura e ideología, existe la posibilidad de que los colores en distintas comunidades lingüísticas tengan valores diferentes e influyan en la captación de la información.

Las obras audiovisuales, como una forma especial de arte, están muy conectadas con los elementos extralingüísticos. Para elegir las palabras más adecuadas en la traducción, describir a los personajes y su psicología y facilitar la comprensión a los espectadores, es imprescindible captar los elementos del contexto extralingüístico y sacar la máxima información posible. Se ha de tener en cuenta la cultura, personajes, estética psicológica y demás factores. Los colores vehiculan informaciones culturales e ideologías.

Conforme las obras audiovisuales transmiten informaciones tanto mediante signos verbales como signos no verbales (imágenes, música, etc.), es inevitable un proceso de “descodificación” en las TAV para convertir los códigos no verbales como los colores en códigos verbales. Así, un lenguaje visual se convierte en otro lingüístico. Dicho proceso se denomina traducción intersemiótica, que interpreta los signos verbales mediante los sistemas de signos no verbales, o viceversa. Al realizar la traducción de un producto audiovisual, que se realiza mediante los recursos de la traducción interlingüística, también es necesario tener en cuenta la información transmitida mediante códigos no lingüísticos.

Nuestro estudio está centrado en las informaciones transmitidas mediante los colores en las obras audiovisuales. Estudiamos el uso de los colores en el caso de la película Hero, en que dicho uso tiene una función narrativa muy importante. Elegimos tres colores principales utilizados en esta película, y a través de la comparación entre sus signifi- 


\section{Lingzhi Nie}

Entreculturas 11 (2021) pp. 105-119

cados connotativos en la película y su posible comprensión por parte de los espectadores hispanos, resumimos los valores perdidos, añadidos o modificados.

La hipótesis con la que partimos en nuestro estudio es que la TAV no siempre puede transmitir todos los valores vehiculados por los colores en una película, y nuestro objetivo es apuntar posibles soluciones ante los problemas que esta hipótesis plantea.

\section{LA PROBLEMÁTICA QUE PRESENTA EL USO DEL COLOR PARA LA TRADUCCIÓN AUDIOVISUAL}

En el año 1906, se utilizó el color por primera vez en una película, de modo que, a partir de entonces, no todas las películas fueron solo en blanco y negro. Hasta hoy, además de ser decorativo, el color puede utilizarse para marcar los cambios de escena, describir la psicología de los personajes, promover el desarrollo de la trama, transmitir valores simbólicos, aludir al contenido real de la película, etc.

Basándonos en las opiniones de Ai Qing (艾青) (2013: 18) y Bi Yifei (毕翼飞) (2015: 12), resumimos las funciones del color en las obras audiovisuales como las siguientes:

1. Explica y profundiza el tema de la película y los personajes. La aplicación de los colores en el cambio de escena y el desarrollo de la trama trae a los espectadores una impresión visual viva y un fuerte atractivo artístico. Al mismo tiempo, los colores transmiten ideas presentes en la película, como sucede, por ejemplo, en la película francesa Tres colores: Rojo dirigida por Krzysztof Kieślowski.

2. De acuerdo con Metz (1968: 55), la misma película tiene una función ficticia y narrativa. Los colores sirven para construir la narración dentro del marco limitado de la película y desarrollar la trama.

Los colores crean un espacio virtual dentro de la película, y este espacio contemplado por los espectadores transmite el aspecto original del mundo real para reforzar las emociones relativas, a la vez que contagia visual y psíquicamente a los espectadores. Este uso se hace evidente en los flashbacks, por ejemplo.
Algunas veces, por necesidad en la presentación, los colores se combinan en las obras audiovisuales a través de la técnica del montaje. El montaje de dos secuencias puede generar un tercer significado; o juntar varias secuencias cortas separadas para comprimir un tiempo y espacio o una información. Los colores funcionan como símbolos de diferentes tiempos y espacios. Describe la trama de una manera específica, se fortalece el sentido real de las imágenes y se dan diferentes emociones psicológicas a los espectadores.

1. Retratan las mentalidades y se expresan las emociones de los personajes. El color es una premisa inconsciente de la película; además, a través de su efecto psicológico, se profundiza en las emociones y las atmósferas. Al mismo tiempo, se expresa el mundo interior de los personajes claramente y puede tener la función de llevar a una catarsis emocional.

La función de crear la atmósfera y sugerir la trama mediante los efectos psicológicos y el conocimiento previo de los espectadores se denomina sinestesia cromática. Aplicado al fenómeno por el que la percepción visual y otros sentidos sensoriales se interrelacionan y provoca que, mediante la visión de los colores, se produzcan las ilusiones sensoriales que refuerzan la percepción. Por ejemplo, los colores cálidos suelen transmitir emociones alegres, y los colores fríos transmiten emociones negativas como depresión, tristeza, miedo, etc. En este sentido, los colores funcionan como una lengua franca.

2. Además de la función de narración y transmisión del espíritu de la película, también se presenta el trasfondo cultural a través de los colores en las imágenes, ya que estos forman parte de la cultura. Por los significados connotados, algunas veces los colores tienen una función simbólica en la película y transmiten una carga cultural.

En resumen, las funciones de los colores se pueden dividir en dos tipos: uno genera la sinestesia cromática que viene determinada por la propiedad física del color; el otro procede de la acumulación de la experiencia cromática y factores humanos y culturales, que viene determinada por los significados connotados de los colores. En nuestro estudio, nos centramos en este segundo tipo. 


\section{LA (IN)TRADUCIBILIDAD DEL PROTOTEXTO AUDIOVISUAL}

Aunque visualmente los colores no varían, cada cultura los codifica de un modo distinto. Por la influencia del medio geográfico, las costumbres locales, formas de pensamiento, religión, factores étnicos y psicológicos, etc., el mismo color provoca distintas asociaciones y tiene diferentes significados connotados para las personas de diferentes comunidades lingüísticas.

Por ejemplo, en España, el negro es un color de luto utilizado habitualmente en los entierros y el color blanco es un color para el vestido de novia en la boda. En cambio, en China, sobre todo en la antigüedad, tanto el negro como el blanco eran símbolos de funeral y sus usos concretos variaban según las circunstancias: para los entierros familiares se vestía de blanco, y para los funerales de guerra o de estado, se vestía de negro.

El desarrollo de los significados connotados de los colores está relacionado con el desarrollo de la cultura espiritual y material de cada comunidad lingüística, por lo tanto es el reflejo de cada cultura. Como los valores asociados varían en diferentes culturas, provocan dificultad en la comprensión y la traducción.

Si bien los significados denotados de los colores son simples, por motivos históricos y culturales, así como también por asociación, sus valores connotados son numerosos e influyen en el pensamiento y el sentimiento de las comunidades lingüísticas.

Las asociaciones y sentimientos causados por la percepción de los colores, que son la base para desarrollar sus significados simbólicos, van cambiando por la diferencia de la ideología entre las diferentes comunidades lingüísticas. No se puede recibir toda la información transmitida en una película sin conocer los significados connotados de los colores utilizados.

La traducción en el ámbito audiovisual implica un transvase de códigos lingüísticos entre más de dos lenguas. Como entre los idiomas mismos ya existen grandes diferencias por la estructura, pensamiento, cultura, etc., con el elemento de los colores añadido, aún aumenta la dificultad para una traducción adecuada. Además, una buena traducción debe cubrir al máximo la información transmitida y conforme al estilo de la película.

Los colores son informaciones no verbales, por lo que son de difícil traducción; sobre todo, cuando no se permite añadir información fuera de la conversación, como suele suceder en la traducción subordinada. Es imposible realizar una interpretación absoluta. Lo único que podemos intentar es conseguir una traducción más apropiada.

Hurtado Albir (2001: 291) define los errores de traducción que causan malentendidos como equivalencias de traducciones inadecuadas, y Delisle (1993: 25-46) clasifica estos errores como: falso sentido, contrasentido, sin sentido, adición, omisión, hipertraducción, sobretraducción y subtraducción. La sobretraducción y la subtraducción son problemas muy frecuentes en el ámbito de la traducción. Según él, la sobretraducción consiste en explicar elementos que deberían quedar implícitos. En la subtraducción, al contrario, no se llega a explicar toda la información transmitida en el original.

Tal y como señala Chaume Varela (2005: 11), “otro de los estándares de calidad de un buen doblaje o subtitulación es que el texto meta sea fiel al texto origen”. Es decir, no se deben añadir ni suprimir informaciones. Por lo tanto, una falta de comprensión de los elementos extralingüísticos implica necesariamente que haya subtraducción o traducción errónea.

La diferencia de cultura causa bastantes problemas para la TAV. Además, las obras audiovisuales se representan de un modo diferente a las obras literarias escritas, y los colores suelen ser símbolos especiales de carga cultural. La comprensión de los colores en las películas, en el fondo, es una transformación de las imágenes culturales. De acuerdo con Martínez Sierra (2004: 152), el papel del traductor es el de "descodificador de la lengua origen y codificador en la lengua de llegada, a la vez que receptor del mensaje en la cultura origen y fuente del mensaje en la cultura meta”.

Las imágenes culturales tienen sus significados connotados y asociaciones relativas. En el proceso de traducción, las conversaciones se trasladan de la lengua de partida a la lengua meta, siendo la imagen y el color lo mismo. Por lo tanto, para los espectadores de una misma cultura no existe ninguna barrera en la comprensión, mientras que, para los espectadores de otra cultura, surgen posibles problemas de interpretación, sobre todo cuando los colores tienen función narrativa o de otro uso especial.

Aunque los colores utilizados en las imágenes influyen en la traducción de una manera indirecta, en el doblaje o 


\section{Lingzhi Nie}

Entreculturas 11 (2021) pp. 105-119

la subtitulación no hay opción para explicar directamente los significados simbólicos de los colores, lo cual provoca que los espectadores de la lengua meta no puedan captar todas las ideas y pensamientos abstractos expresados mediante las imágenes.

Además, existen limitaciones específicas en la TAV, tales como la restricción temporal y la sincronía de los enunciados de los actores en la pantalla, "el respeto a los movimientos bucales, corporales"; "la coherencia entre palabras e imágenes, así como la coherencia interna del hilo narrativo argumental, y la cohesión de los diálogos" (Chaume Varela, 2005: 5-12), la limitación de tiempo en pantalla; la coincidencia del estilo de película y personaje, etc., todo ello aumenta la dificultad en dar con una traducción adecuada y restringe el repertorio de posibles soluciones.

\section{EL USO DEL COLOR EN LA PELÍCULA HERO}

La película presenta una ficción desarrollada en tiempos de conflictos bélicos cuando China estaba dividida en siete reinos. Durante años, los reinos luchan entre sí para obtener la supremacía, y el personaje del Rey de Qin es el más implacable. El pueblo considera que, una vez muera, el mundo quedará otra vez en paz. En este contexto, el personaje Sin Nombre es uno de los asesinos en la película, como se descubre al final. Entre el personaje del Rey de Qin y el personaje Sin Nombre sostienen una conversación para descubrir la verdad sobre las muertes de los tres asesinos: Cielo, Espada Rota y Nieve Voladora.

Los personajes visten de color negro, rojo, amarillo, azul, verde y blanco según la necesidad en la narración. Tal y como indica Ye Jing (叶菁), la evolución de colores oscuros a colores claros sugiere a los espectadores un acercamiento gradual de la narración a la realidad. La historia se narra en cuatro versiones hasta descubrir la verdad. El diálogo envuelto en color negro describe la lucha entre el personaje Sin Nombre y Cielo. La narración en color rojo es una historia inventada por el personaje Sin Nombre con el objetivo de ganarse la confianza del Rey y matarlo, y en esta parte ha introducido el color amarillo para crear un fondo triste.
El relato imaginado por el personaje del Rey es de color azul para sacar la verdad sobre las muertes de los personajes asesinos y el motivo del acercamiento del personaje Sin Nombre. La explicación del personaje Espada Rota para convencer al personaje Sin Nombre de no matar al Rey está en color verde para mostrar el deseo de paz. En el momento en que el personaje Sin Nombre descubre la realidad de la historia, se utiliza el color blanco, que hace referencia a la verdad, la muerte y el fracaso.

Por el uso de los distintos colores se ha explotado el marco limitado de la pantalla extendiéndose al espacio abierto, aunque las diversas narraciones transcurren en el palacio imperial cerrado de Qin. Por un lado, se aumenta el impacto visual de la pantalla con estos colores individuales y fuertes; por otro lado, se muestran conceptos de la filosofía taoísta, tales como tianrenheyi (天人合一), 'la armonía entre la naturaleza y la humanidad', bagua (八卦), 'ocho estados de cambio'1, wuwei (无为), 'sin acción'2, dayinxisheng (大 音希声), 'la gran música tiene las notas más débiles', daxiangwuxing (大象无形), 'la gran forma es sin forma', incluso wuxing (五行), 'cinco elementos: metal, madera, agua, fuego, tierra', wuse (五色), 'blanco, qing (verde/azul), negro, rojo, amarrillo', wushou (五兽), 'dragón azul, tigre blanco, fénix bermellón, tortuga negra, qinlin’' . A través de la tabla siguiente, vemos la relación entre los cinco elementos, cinco colores, cinco orientaciones y cinco animales.

1 Un símbolo de origen chino que está compuesto por ocho trigramas ordenados de una manera determinada alrededor de un centro, el yinyang. Es un símbolo sencillo formado con negro y blanco solo, pero puede explicar una filosofía complicada y profunda. A través de las distintas combinaciones de Bagua, no sólo se puede representar distintos fenómenos y movimientos en la naturaleza, también se puede explicar la filosofía china, incluso las teorías de médico tradicional, Kung Fu, música, etc., están afectadas.

2 El importante aspecto de la filosofía taoísta en el cual se destaca que la forma más adecuada de gobernar es no actuar o no forzar.

3 Tanto dayinxisheng (大音希声), 'la gran música tiene las notas más débiles' como daxiangwuxing (大象无形) , 'la gran forma es sin forma', se refieren a que lo último es difícil de alcanzar y no se puede tentar.

4 Animales de un cuerno imaginados en la mitología china que tienen características de dragón chino. 
TABLA 1. Relación entre los cinco elementos, cinco colores, cinco orientaciones y cinco animales

\begin{tabular}{cccc}
\hline ELEMENTOS/MATERIALES & SERIE DE COLOR & ORIENTACIÓN & ANIMAL \\
\hline Fuego & Chi (赤), 'rojo' & sur & fénix bermellón \\
\hline Madera & Qing (青), ‘verde azulado' & este & dragón azur \\
\hline Tierra & Huang (黄), ‘amarillo' & centro & qinlin (麒麟) \\
\hline Metal & Bai (白), ‘blanco' & oeste & tigre blanco \\
\hline Agua & $H e i$ (黑), 'negro’ & norte & tortuga negra \\
\hline
\end{tabular}

Se considera que entre los colores, animales, estaciones, elementos, etc., existe una relación, a través de la cual se forman los significados simbólicos, esto queda reflejado en la película Hero en la cual han utilizando los cinco colores de la tabla.

Por la influencia del pensamiento de wuxing (五行), 'cinco elementos: metal, madera, agua, fuego, tierra', el reino de Qin se opone al de Zhou del mismo modo que el agua se opone al fuego. Por este motivo, se utiliza el negro para la tropa, la bandera, las prendas, el palacio, etc. El negro es el color más noble en el reino de Qin.

El color rojo siempre se define como el símbolo de China. En los tiempos de conflictos bélicos, por el pensamiento de que la madera alimenta al fuego, la bandera del reino Zhao es de color rojo y azul. En la película se utiliza el rojo para representar el reino de Zhao y se aplican sus significados simbólicos en la narración de dicho color.

En la película Hero, que habla del conflicto entre el reino Qin y el de Zhao, se utilizan abundantemente estos dos colores.

El azul es un color racional. En esta parte de narración, se ha mezclado la conversación entre el personaje Sin Nombre y el personaje Espada Rota en color verde. Según la filosofía wuxing (五行), 'cinco elementos: metal, madera, agua, fuego, tierra', qing (青), 'verde azulado', que mezcla verde y azul, está vinculado con la orientación este y el animal dragón azur, es el símbolo de fuerza.

Se utiliza el amarillo en varias narraciones. Según la cultura china, amarillo es el color de la tierra y representa el centro. Es el símbolo del espíritu nacional. Se muestra el personaje Cielo y sus caracteres a través de su vestido de color amarillo. Al mismo tiempo, es un color triste cuando se relaciona con las hojas caídas.

Según la cultura china, se vincula el blanco con el oeste y con el tigre blanco. Por un lado, muestra la pureza e inocencia del interior de los personajes asesinos; por otro lado, en el espacio blanco transmite un sentimiento de pérdida y de duda ante la finalidad de asesinar al Rey.

\section{ANÁLISIS Y COMPARACIÓN DE LOS VALORES CONNOTADOS DE TRES DE ESTOS COLORES EN CHINO Y EN ESPAÑOL}

En este artículo, nos centramos en tres de los colores utilizados en la película Hero: negro, rojo y azul. Explicamos el uso de cada color en concreto y del valor que la lengua y la cultura china asocian a este color, al mismo tiempo que hacemos la comparación con sus significados connotados en español.

\subsection{Negro}

El tono general, así como el color predominante que utiliza la película Hero, es el negro. El color negro es el hilo conductor de la película y coincide también con el tema principal.

Para analizar el negro, nos basamos en Xinhua zidian (新华字典), 'diccionario Xinhua' (2015: 63/185/188/280),y junto con las críticas de Ai Qing (艾青) (2013: 18) y Ye Jing 


\section{Lingzhi Nie}

Entreculturas 11 (2021) pp. 105-119

(叶菁) (2012: 142-143). Según el diccionario y los críticos de Ai Qing (艾青) (2013: 18) y Ye Jing (叶菁) (2012: 142143), en la película, el color negro se asocia con el reino de Qin, con el poder, así como también con la autoridad, la determinación, la tradición y el misterio. Además, se relaciona con la tensión, la indiferencia, la crueldad, la traición, la soberbia y la muerte. $\mathrm{Al}$ mismo tiempo, a medida que avanza la película, sirve para reforzar el ambiente serio, peligroso, apesadumbrado y depresivo.

En la cultura china, el negro desempeña un doble papel por sus significados simbólicos. Por un lado, es un color de dignidad.

1. Se aplica mucho el negro para las prendas y es un color noble en el periodo presentado en la película, sobre todo en el reino de Qin. Por lo tanto, el negro representa el reino de Qin y el Rey de Qin, y todos los personajes relacionados con $Q$ in van vestidos con dicho color.

2. Como el negro se asocia con el hierro, en chino connota honestidad y valor. En la ópera de Pekín, se utiliza el negro para representar un personaje valiente y honesto. En la película, el personaje Sin Nombre viste de negro, que representa su carácter valiente, firme y persistente, y tiene un gran corazón que se preocupa por las vidas de todas las personas bajo el cielo.

3. Por la influencia del pensamiento taoísta sobre el $b a$ gua (八卦), 'ocho estados de cambio' y wuwei (无为), 'no acción', el color negro puede connotar el grado supremo. En la filosofía taoísta, el último grado es perfecto y ningún color ni sonido lo describe, sino que más bien se debe sentir. En la película, se indica que el nivel de Kung Fu del personaje Sin Nombre y Cielo es lo bastante alto para ser maestro.

Por otro lado, como el negro se asocia con el invierno, a lo largo de la historia se han generado muchos significados connotados despectivos.

1. Es un color que se asocia con la política. Tiene el significado figurado para representar la rebelión reaccionaria y ser el símbolo de la crueldad; por ejemplo, el dicho chang heilian (唱黑脸), 'cantar con la cara negra', que puede significar que, cuando alguien gestiona sus asuntos, trata de ser honesto e imparcial e insiste en sus principios; o la expresión heibang (黑帮), 'partido negro', que se refiere a una banda de delincuentes u otros grupos criminales y sus miembros que actúan en contra de un sistema establecido. En la película Hero, el negro se hace extensivo a la autoridad, la dominación de la realeza, la dictadura del personaje del Rey, el poder imperial supremo, la fuerza poderosa e inviolable y la realeza. El personaje del Rey y sus tropas son fríos y despiadados.

2. Es un símbolo pasivo y representa las fuerzas negativas. Tal y como se define en el diccionario, heise kongbu (黑色恐怖), 'el terror negro' se refiere a las actividades criminales, anarquistas o terroristas. En la película, el predominio del color negro va asociado a los temibles daños que han traído al pueblo el terror y la tensión de la dictadura.

3. Así mismo, representa las fuerzas de los conservadores, que son duras, fuertes, despiadadas e inflexibles. De acuerdo con Ye Jing (叶菁), cuando, al final de la película, los ministros vestidos con prendas negras exigen al Rey dubitativo que ejecute la pena de muerte, ellos están mostrando una fuerza que se opone a la razón.

4. En la cultura china, el blanco es un color tabú y tiene el significado connotado de la muerte. Sin embargo, no es el único color vinculado con el luto. Como el negro tiene el significado connotado de solemnidad, también se aplica en el rito fúnebre para expresar el pésame, aunque muchas veces simplemente se muestre en una pieza de tela de color negro situada en el brazo, el zapato $u$ otros sitios. Por lo tanto, el negro se relaciona con el pésame y la muerte.

5. En la película, tanto el personaje Sin Nombre como el personaje del Rey visten de negro para sugerir que de sus decisiones dependen numerosas vidas. Como señala Ye Jing (叶菁), a través del negro se expresa que el poder de Qin se basa en la muerte y la sangre de muchos destinos trágicos del pueblo. Al final de la película, cuando los ministros están pidiendo al Rey que condene a muerte al personaje Sin Nombre, con el color negro llenando la pantalla, los espectadores pueden deducir con tristeza el destino final del personaje Sin Nombre. 


\section{LA (IN)TRADUCIBILIDAD DEL PROTOTEXTO AUDIOVISUAL}

Entreculturas 11 (2021) pp. 105-119

Así mismo, la pantalla llena de negro expresa condolencia por los héroes caídos.

6. Tal y como explica Xinhua Zidian (新华字典), 'diccionario Xinhua' (2015: 185), el negro tiene el valor connotado de mala suerte o poca fortuna. En la película, nos transmite la idea de que el personaje Sin Nombre no puede sobrevivir en el palacio imperial.

Además de estos significados connotados, el uso del negro tiene estas funciones especiales en la película:

1. Tal y como advierte Ai Qing (艾青), la narración se construye mediante colores dentro del marco limitado de la película. Se utiliza el negro para representar que parte de la lucha explicada por el personaje Sin Nombre es una ficción.

2. Por otro lado, el negro y el blanco también se emplean para expresar las mentalidades en este ámbito. A diferencia de una lucha normal, parte del enfrentamiento se realiza en la imaginación de los dos personajes. Con el color negro, se expresa que la lucha es en parte mental.

3. En el ámbito audiovisual, cuando se quiere mostrar una realidad sin añadir emoción personal, a menudo se usa el blanco y el negro en lugar del color. De acuerdo con Ye Jing (叶菁), la narración del personaje Sin Nombre sobre la historia en el pabellón de Ajedrez es triste: el personaje Cielo ha sacrificado su vida confiando en que él cumplirá su parte de la misión. El personaje Sin Nombre lo narra con voz plana, como si no tuviera sentimientos.

4. Además, como el negro es un color de desesperación, se utiliza para aludir al triste destino de los protagonistas y reforzar el ambiente depresivo. A la vez que promueve la trama, sugiere que el personaje Sin Nombre no puede matar al Rey de Qin y tampoco puede salvarse.

A continuación, basándonos en la definición del color negro y de los dichos españoles que contienen este color según el DLE (2014: 1530), estudiaremos los significados connotados que pueden asociar los espectadores hispánicos.

Según el diccionario, los hablantes de español suelen relacionar el color negro con significados connotados ne- gativos, como, por ejemplo, la ilegalidad. A partir de un significado básico, se amplían más significados derivados o relativos.

Valor 1: Ilegalidad.

Valor 1.1: Muy sucio;

Valor 1.2: Clandestino, ilegal;

Valor 1.3: Trabajo anónimo.

Valor 2: La fuerza pasiva misteriosa.

Valor 2.1: Poder maligno que denota misterio;

Valor 2.2: Ambiente criminal y violento.

Valor 3: El color del luto, alejado de la alegría. En español, el negro es el color del luto, y connota muerte o falta de alegría. Estos valores se concretan en los siguientes:

Valor 3.1: Mala suerte;

Valor 3.2: Muerte, luto;

Valor 3.3: Pésame;

Valor 3.4: Extremadamente triste, melancólico y penoso;

Valor 3.5: Infeliz, infausto y desventurado;

Valor 3.6: Muy enfadado o irritado.

Valor 4: Falta de comprensión o ausencia de provecho.

Valor 5: Condición pobre y dudosa.

Valor 5.1: Apuro, dificultad o complicación;

Valor 5.2: Quedarse sin dinero.

Los valores 4 y 5 pocas veces se utilizan en el ámbito audiovisual. Vemos que, en el caso del color negro, los significados connotados no varían mucho entre el chino y el español. En ambas lenguas, el negro se asocia con la tristeza, la muerte, la mala suerte, el pésame, la fuerza negativa y el ambiente criminal y violento. Es decir, toda la información que está relacionada con los significados connotados despectivos en chino para los espectadores españoles tampoco les resulta difícil de percibir.

Sin embargo, a diferencia de su uso en español, el negro en la lengua china también tiene significados connotados positivos y esta parte sí que se escapa a la percepción de los espectadores hispánicos. 


\section{Lingzhi Nie}

Entreculturas 11 (2021) pp. 105-119

Aunque el papel especial que juega el negro en el ámbito audiovisual es bastante compartido por ambas comunidades lingüísticas, por influencia del taoísmo, en Hero tiene el uso especial de expresar el nivel de Kung Fu de los personajes Sin Nombre y Cielo, y este valor también queda fuera del alcance de los hablantes hispánicos.

\subsection{Rojo}

La narración en rojo habla de la guerra entre los dos reinos y del sacrificio. De acuerdo con Ye Jing (叶菁) (2012: 142-143), representa un tipo de héroe vengativo. Se asocia el color rojo directamente con el reino de Zhao, la sangre, la furia, los celos, el peligro, la desesperación, la venganza ciega, la ambigüedad de la relación y un amor que provoca daños a ambas partes.

A continuación, integramos los sentidos del color rojo tal y como aparecen en el diccionario y la trama de la película Hero, y estudiamos los significados simbólicos relativos. En chino, los significados connotados del rojo son principalmente positivos:

1. Según la definición de honglian (红脸), 'cara roja' en el diccionario, sabemos que el rojo tiene el significado connotado de justicia y fidelidad. En la ópera de Pekín, se suele maquillar roja la cara de los personajes de héroes y oficiales leales a su soberano. En la película Hero, el rojo también se utiliza para referirse a la virtud y el patriotismo de Zhao, la defensa firme de la cultura tradicional y la hostilidad a Qin. Es un color de patriotismo y fidelidad.

2. A partir de su significado de fidelidad y justicia, se ha ampliado el valor simbólico de espíritu caballeresco y héroe.

De acuerdo con Ye Jing (叶菁) (2012: 142-143), el conflicto entre el negro y el rojo a lo largo de la película es en realidad un conflicto entre el sistema de la realeza y el espíritu caballeresco. Tanto los asesinos como el Rey son héroes que han llegado a serlo mediante la propia sangre y sacrificios o a través de la sangre ajena y la represión de los enemigos.
3. En la modernidad, por motivos políticos, el rojo también ha tenido el significado connotado de referirse a la revolución. La intención de los asesinos de acabar con la vida del rey es justamente una revolución para oponerse a la crueldad del monarca, que ha provocado un gran perjuicio para el pueblo.

4. Por la influencia de la filosofía de wuxing (五行), 'cinco elementos', el color rojo connota el reino de Zhao y todo lo que va relacionado con él.

Sin embargo, el rojo también tiene significados connotados negativos:

1. Por la influencia de la lengua inglesa, en chino existe la expresión hongdengqu (红灯区), 'zona roja', que corresponde a la inglesa "red-light district". De ahí, el rojo también puede connotar una relación sexual de naturaleza inmoral, ambigua o peligrosa.

Esta connotación está presente en la relación entre el personaje Espada Rota y el personaje Luna. El sufrimiento que provoca esta relación irracional llega a su máximo cuando las hojas amarillas cambian a rojo después de que el personaje Nieve Voladora mata al de Luna.

2. Así mismo, en la cultura china el rojo se asocia al fuego y puede connotar todas las pasiones, tanto de amor como de odio.

En la película, simboliza la relación entre el personaje Espada Rota y el personaje Nieve Voladora, llena de desesperación a causa de los celos, los malentendidos y la falta de confianza. Los dos personajes se hacen daño mutuamente y sufren por la falta de comunicación: una relación basada meramente en la pasión no es estable ni racional.

3. Como el rojo altera o estimula los nervios, además de la pasión, ser vehemente es su otro significado connotado. En la película, sirve para mostrar el desasosiego y la furia del narrador, el personaje Sin Nombre, y de su pareja.

Puesto que la historia que cuenta es ficticia, es inevitable que el narrador se sienta inquieto y nervioso. Así 


\section{LA (IN)TRADUCIBILIDAD DEL PROTOTEXTO AUDIOVISUAL}

Entreculturas 11 (2021) pp. 105-119

mismo, el conflicto entre la pareja es causa de furia y celos, lo cual provoca a ambas partes un gran sufrimiento e indignación, puesto que además llevan tres años sin hablarse. La relación de los dos, al final, es una discrepancia basada en factores irracionales.

4. El rojo es el color de la sangre, y la sangre es el origen de la vida. En consecuencia, en chino el rojo connota también arrebatamiento irracional. El camino para asesinar al Rey es irracional y lleno de incertidumbre.

5. El color de la sangre también simboliza la violencia y la hostilidad. Tanto los daños causados por la dominación del Rey como por la revolución del pueblo y de los asesinos son de naturaleza violenta: la invasión de Zhao por parte de las tropas de Qin, los destinos trágicos de los personajes, la hostilidad de los personajes que intentan asesinar al Rey, etc. Con la utilización del color rojo se sugiere la atrocidad de Qin y el odio inherente a la guerra.

Además, desde el punto de vista audiovisual, el rojo tiene las siguientes funciones especiales en la película.

1. Señala Ai Qing (艾青) (2013: 18) que, a través de la tensión y el impacto visual del rojo muy vivo, se fortalece la atmósfera. El rojo, como vehemente que es, promueve el desarrollo de la trama.

2. Se ha constituido un engaño ficticio lleno de sangre dentro del marco limitado de la película: la sangre del personaje Espada Rota, del personaje Luna y del personaje Nieve Voladora. Así mismo, la exageración de rojo coincide con el sentimiento inquieto y hostil del narrador.

3. Además, como observa Ye Jing (叶菁) (2012: 142-143), el rojo es un color que denota irracionalidad. A través de la tonalidad roja se muestra el grado de impaciencia. Los caracteres de los personajes se explican con distintos rojos: el rojo vivo representa los caracteres maduros y fríos de los personajes Espada Rota y Nieve Voladora; y el rojo anaranjado representa el carácter poco experimentado y paciente del personaje Luna.

En español, el rojo desempeña un doble papel. Es un color de la alegría y del peligro, del amor y del odio.
Valor 1: La revolución y los partidos de izquierda.

Valor 1.1: La cualidad izquierdista, radical y revolucionaria, especialmente comunista y republicana;

Valor 1.2: La libertad, el socialismo y el estado soviético.

Valor 2: Confianza.

Valor 2.1: El coraje;

Valor 2.2: La actitud optimista ante la vida.

Valor 3: Las emociones y la violencia.

Valor 3.1: El estado emocional como la vergüenza, la ira, la rabia, la impaciencia, la ambición, la vitalidad, la alegría, la pasión, el amor, el deseo, etc.;

Valor 3.2: La violencia y la agresividad.

Valor 4: El peligro y la advertencia.

Valor 4.1: El peligro y lo prohibido;

Valor 4.2: La advertencia.

Valor 5: Lo sexual y lo inmoral.

Valor 6: El estado ardiente.

Valor 6.1: Un estado de gran excitación, de ánimos muy alterados;

Valor 6.2: Un estado muy caliente e incandescente;

Valor 6.3: La fama.

Vemos que los valores 6.2 y 6.3 no son muy relevantes en el ámbito audiovisual. El rojo tiene otros significados connotados en español que tampoco van a ser muy relevantes en los productos audiovisuales.

Valor 7: Con respecto a la posición, se refiere a la persona, equipo o grupo que ocupa el último lugar, sobre todo en una competición.

Valor 8: En el ámbito de las finanzas, se refiere al déficit fiscal, el déficit presupuestario o el déficit público.

A través de la comparación, e integrándola con las tramas de la película, observamos que, para los espectadores de ambas comunidades lingüísticas, el rojo se puede referir a la revolución. Es un color que se relaciona con la sangre y comparte los significados connotados relacionados con las 


\section{Lingzhi Nie}

Entreculturas 11 (2021) pp. 105-119

distintas emociones y la irracionalidad. Además, en ambas lenguas es un color que advierte de la relación peligrosa entre el personaje Espada Rota y el personaje Nieve Voladora. Tampoco resulta difícil vincular el rojo con los líos de una noche e imágenes violentas.

Sin embargo, la mayoría de los significados connotados del rojo en español son despectivos. Para los espectadores hispánicos, por desconocimiento de la cultura china, resulta imposible relacionar el rojo con el Reino de Zhao o con el patriotismo y la fidelidad del pueblo. Aunque en español el rojo se puede referir al coraje, sigue siendo difícil vincular este color con el espíritu caballeresco propio de los héroes.

\section{$4.3 \mathrm{Azul}$}

Según la filosofía china, el azul está incluido dentro de qing (青), que es un color mezclado del azul y del verde. En la película Hero, las dos tonalidades principales de qing (青) se han separado en estos dos colores. En este artículo, nos centramos en el color azul.

De acuerdo con Ye Jing (叶菁) (2012: 142-143), en la película, el azul se asocia con la mente, la calma, la firmeza; también con el asesinato. En la narración del color azul, el personaje del Rey de Qin desprende la muerte de los personajes Espada Rota y Nieve Voladora, en una trama que contiene una historia romántica.

Integrado con las tramas de la película, el azul tiene los siguientes significados simbólicos:

1. En chino, qing (青) connota la nobleza del espíritu. Tal y como apunta Ye Jing (叶菁) (2012: 142-143), corresponde a la mejor virtud del agua según la filosofía taoísta, ayuda a todos y no compite con nadie.

En la película, por un lado, se asocia con el espíritu de los personajes Sin Nombre y Espada Rota. Ambos al final han renunciado a los beneficios personales para contribuir a la unificación. Por otro lado, es el símbolo del espíritu heroico. Para el Rey de Qin, la pareja de asesinos tiene un carácter noble y virtuoso. El amor entre los dos es muy profundo, hasta el punto de sacrificar su vida mutuamente.
2. Según la filosofía wuse (五色), 'cinco colores', el azul está vinculado con el dragón azul y tiene el significado simbólico de fuerza y coraje. En la película se refiere a la intrepidez del personaje Sin Nombre. La imagen del cielo azul antes del enfrentamiento con el Rey de Qin revela su carácter valiente y decidido.

3. El azul es un color frío que se asocia con la mente. Connota la sabiduría.

En la película, el personaje del Rey no cree las palabras del personaje Sin Nombre y muestra respeto hacia la pareja de asesinos. A través del color azul, muestra una imagen de monarca sabio y perspicaz, con abierta simpatía hacia las personas con talento.

4. Como el azul es un color tranquilizante, connota imperturbabilidad. En la película expresa un estado de ánimo tranquilo.

Por un lado, aunque conoce perfectamente la intención y la identidad del personaje Sin Nombre, el Rey de Qin sigue estando tranquilo. Por otro lado, el duelo entre el personaje Sin Nombre y el personaje Espada Rota que comporta el sacrificio del personaje Nieve Voladora se realiza al lado de un lago tranquilo y azul. A través del azul, se refleja su estado de ánimo. Lejos del rencor o del antagonismo, la lucha simplemente es una vía de solución del conflicto entre los dos héroes.

5. Así mismo, por influencia de la cultura occidental, el azul ha tomado la connotación de tristeza y de fidelidad. En la película, el color azul representa el amor romántico, triste y eterno, entre la pareja de asesinos.

El azul también tiene significados connotados negativos en chino:

1. Por ejemplo, el qing (青), ‘verde azulado’ se puede utilizar para describir a personas con una faz feroz. La fórmula qingmian liaoya (青面獠牙), 'cara de color qing y colmillos largos' se utiliza para describir a las personas cuya cara recuerda la de una fiera. En la película Hero, a través de imágenes llenas de color azul, se expone la parte cruel de la guerra. 


\section{LA (IN)TRADUCIBILIDAD DEL PROTOTEXTO AUDIOVISUAL}

Entreculturas 11 (2021) pp. 105-119

Además de todas estas funciones simbólicas, desde el punto de vista audiovisual, el azul en esta película sirve para:

1. Constituir la mentalidad del personaje del Rey dentro del marco limitado de la película. A través del azul, nos representa su deducción sobre la muerte de los personajes Espada Rota y Nieve Voladora;

2. Constituir un mundo tanto realista como fantástico. En el duelo entre el personaje Sin Nombre y el personaje Espada Rota por el sacrificio del personaje Nieve Voladora, se divide el agua en dos colores: el azul del agua, y el verde de las montañas reflejadas en el lago. Se genera un mundo en el que coexisten la realidad y la ilusión;

3. Relajar a los espectadores. El azul claro ayuda a relajarse, de modo que alivia la tensión visual y mental causada por las demás narraciones;

4. Generar una atmósfera peligrosa, sobre todo con el azul oscuro, el cual se asocia al asesinato. Como el exceso de azul causa depresión, sirve para crear una atmósfera peligrosa y triste;

5. Potenciar el ambiente triste con el fin de que el público sienta pena por el sacrificio de los personajes asesinos.

En español, el azul sigue siendo un color frío y distante.

Valor 1: Se relaciona con el conocimiento y entendimiento.

Valor 1.1: Las cualidades intelectuales;

Valor 1.2: La paz y la tranquilidad;

Valor 1.3: El carácter valiente, imperturbable y racional.

Valor 2: Por la asociación con el cielo, se refiere a la eternidad y depresión.

Valor 2.1: La eternidad y permanencia (tonos claros);

Valor 2.2: La depresión (tonos oscuros).

Valor 3: La fidelidad y las virtudes espirituales.

Valor 3.1: La cualidad o linaje noble, la generosidad;

Valor 3.2: Pareja ideal soñada o esperada por las mujeres.
Valor 4: Otros significados connotados por el uso privativo de este color, de poca relevancia en el ámbito audiovisual:

Valor 4.1: En el ámbito político, el azul se refiere a la extensión del gobierno, generalmente al Gobierno de la Nación;

Valor 4.2: En el ámbito del medio ambiente, se refiere a la buena calidad del agua, por el color usado en las banderas, sobre todo, en playas y puertos;

Valor 4.3: Por el color de la gorra, para las Naciones Unidas, el azul se refiere a las fuerzas neutrales en zonas conflictivas;

Valor 4.4: En el ámbito médico, se refiere al estado de cianosis permanente.

Vemos que, para el color azul, en ambas lenguas se comparten muchos significados positivos, tales como la nobleza, la intrepidez, la sabiduría, la tranquilidad, la eternidad y la fidelidad. Para los espectadores hispánicos, no les cuesta percibir estos significados simbólicos en la película Hero.

Sin embargo, en chino, el azul también se refiere al carácter feroz. A través del azul, se nos representa la crueldad de la guerra. Además, aunque el azul tiene la connotación de nobleza y generosidad en español, este significado connotado no es equivalente al chino, que está relacionado con las propiedades del agua. En la película, alude al esfuerzo por superar las limitaciones del pensamiento y conformarse a la tendencia de la unificación.

\section{CONCLUSIÓN: ¿TRADUCIBLES O INTRADUCIBLES?}

A partir de la comparación que hemos hecho, vemos que, ya sea por el intercambio cultural o por otros motivos, los hablantes chinos y españoles, cuyas lenguas y culturas son diferentes, comparten una parte de las connotaciones asociadas a los colores. Sin embargo, tampoco podemos tomar los colores como una lengua franca. Algunas de sus connotaciones son complejas, por lo tanto puede resultar difícil interpretarlas en su totalidad.

Según el análisis de tres de los colores en la película Hero, observamos que las funciones especiales que tiene 


\section{Lingzhi Nie}

Entreculturas 11 (2021) pp. 105-119

cada color en el ámbito audiovisual no varían mucho, y lo que dificulta su comprensión son los valores con cargas culturales. Para el espectador en la versión traducida, frecuentemente les cuesta percibir los significados que solo existen en la lengua de partida, y por influencia de los valores en la lengua meta, es posible que añada o modifique información. Además, cada trama explota unos valores determinados de los colores en el ámbito audiovisual.

En las obras audiovisuales, los colores no se presentan de forma verbal, sino visual. Además, para no romper la belleza total de la película, suele utilizarse colores con funciones específicas sin añadir informaciones suplementarias. Por lo tanto, es imprescindible, hasta cierto punto, que sean los mismos espectadores los que perciban la información transmitida por la película original.

Tal y como ocurre en el caso de Hero, por tener conocimientos inadecuados o insuficientes, es muy posible que el espectador interprete de una manera inadecuada el significado de los colores: puede que añada, pierda o deforme la información. En este sentido, podría ser muy útil hacer un estudio basado en un cuestionario entre los espectadores hispanohablantes de la película para obtener datos reales sobre este proceso.

La calidad de la TAV afecta directamente a la comprensión de la película en los espectadores. Para una traducción adecuada, es imprescindible captar la información del contexto, sobre todo, del contexto extralingüístico. A diferencia de las traducciones literarias, por ejemplo, la TAV impone unos requisitos muy determinados al traductor. Requiere un análisis exhaustivo sobre los posibles puntos difíciles y los elementos del contexto extralingüístico para utilizar una estrategia adecuada en la traducción.

La TAV no consiste en textos solo verbales, sino en una integración de las imágenes, sonidos, colores y demás códigos no verbales. El contexto extralingüístico tiene una influencia que no podemos ignorar. Sin duda la comprensión de las informaciones culturales y los signos no verbales trae problemas a la TAV.

Una de las limitaciones principales en la TAV es la del tiempo: la traducción en la lengua meta no puede ser más larga que el original de la lengua de partida. Un traductor audiovisual ha de saber la importancia del contexto extralingüístico y conocer el trasfondo cultural para captar el entorno, los caracteres de los personajes y las mentalidades correspondientes. Al mismo tiempo, el traductor necesita tener siempre en cuenta los hábitos lingüísticos y las tradiciones estéticas, así como la capacidad de percepción inmediata de los espectadores, e integrar su traducción en el contexto extralingüístico. Según el estilo de la película, el traductor deberá elegir unas palabras u otras.

En cuanto a los colores que tienen varios significados connotados, no siempre se puede interpretar la información que transmiten de manera literal. Hay que tener un conocimiento suficiente de la lengua y la cultura para dar con la traducción más adecuada al contexto.

Por ejemplo, en la película Hero, el director utiliza el negro para mostrar el nivel de Kung Fu de los personajes Sin Nombre y Cielo. Sobre la lucha entre estos dos personajes, la versión china señala que tanto en música como en artes marciales es dayinxisheng (大音希声), 'sonido grande, poca voz'. De esta frase, hay varias explicaciones en China:

1. La mejor música está fuera de nuestro alcance y no tiene sonido.

2. La mejor música no es para escuchar con los oídos, sino para sentirla.

3. La mejor música enfatiza la armonía con la naturaleza. La mejor música es el sonido de la naturaleza.

La versión española lo traduce como "ambas buscan la armonía suprema”. La subtitulación española lo traduce como: "ambas enfatizan el alcanzar un estado supremo". Según la trama posterior en la película, sabemos que la lucha empieza con la rivalidad de las fuerzas interiores en la imaginación. En esta parte, el director no solo utiliza el negro para describir la armonía que reina en el salón de ajedrez, sino también para destacar el sentimiento y la lucha de las fuerzas interiores. Para ayudar a los espectadores a entender este concepto, quizás se podría haber elegido una traducción más directa: "la armonía suprema es sentir / imaginar / la interior".

De acuerdo con el traductor Qian Shaochang (钱绍昌) (2000: 61-65), el lenguaje audiovisual, a diferencia del len- 


\section{LA (IN)TRADUCIBILIDAD DEL PROTOTEXTO AUDIOVISUAL}

Entreculturas 11 (2021) pp. 105-119

guaje escrito, dispone de cinco características: auditivos, extensos, instantáneos, populares, en los que es difícil incorporar información. La rapidez de las imágenes impide que los espectadores tengan mucho tiempo para reflexionar sobre lo que están viendo. Por lo tanto, el traductor debe transmitir la información del modo más sintetizado posible para guiar su comprensión. Como es necesario mantener la belleza total de las imágenes, las TAV no pueden interpretar todas las informaciones no lingüísticas mediante palabras. Necesariamente debe confiarse en la percepción individual de los espectadores. Lo mejor que puede hacer una TAV es guiar el sentido de la comprensión de los espectadores para que no se desvíe mucho de la ruta adecuada. Para esto, el traductor ha de informarse suficientemente sobre el trasfondo cultural antes de realizar una traducción. Cómo guiar a los espectadores también es un arte que requiere el dominio de las lenguas y culturas tanto de partida como de llegada al traductor.

Aún admitiendo que la información verbal es el principal papel, hay que tener en cuenta la información no verbal como la música, el color, la imagen, etc. Las dos informaciones se complementan para conformar el conjunto de la película. Mediante la información verbal y no verbal, los espectadores consiguen comprender mejor la película.

Los códigos culturales suelen tener significados fijos y típicos, a la vez que hay otros que surgen a través de numerosas asociaciones. El color por sí mismo en las películas desempeña un papel de imagen cultural, y ayuda a los espectadores de la lengua de partida a comprender el trasfondo de lo que se muestra en las imágenes. Los traductores audiovisuales deben ser conscientes de ello y buscar soluciones que permitan que los espectadores de la lengua meta comprendan los valores artísticos y sociales y tengan una experiencia similar a la de los espectadores de partida, a fin de que la comunicación intercultural sea un éxito.

Los valores connotados de los colores utilizados en las obras audiovisuales pueden transmitir valores culturales que, junto con las restricciones propias de la TAV, pueden suponer un obstáculo para el traductor. En esta encrucijada, lo único que el traductor puede hacer es intentar orientar adecuadamente la traducción mediante un buen conocimiento de la lengua y la cultura de partida y una cuidadosa elección de las palabras en la lengua de llegada.

\section{REFERENCIAS BIBLIOGRÁFICAS}

Ai Qing (艾青) (2013): “Guanyu dianying Yingxiong zhong meishu de secai yunyong tantao (关于电影《英雄》中美术 的色彩运用探讨)” [El análisis de la aplicación de arte de los colores en la película Hero], Zhongguo lunwen wang (中国论 文网). En línea] http://www.xzbu.com/7/view-4398203. htm [consulta: 18 de marzo de 2016].

Bi Yifei (毕翼飞) (2015): “Lun secai zai yingshi zuopin zhong de zhongyao zuoyong (论色彩在影视作品中的重要作用)” [Las funciones importantes de los colores en las obras audiovisuales], Zhongguo lunwen wang (中国论文网). [En línea] http://www.xzbu.com/7/view-6099908.htm [consulta: 20 de marzo de 2016].

Burad, Viviana (2009): "Una teoría interpretativa para el binomio lengua de señas - lengua hablada", Culturasorda. [En línea] https://cultura-sorda.org/wp-content/ uploads/2015/03/Burad_teoria_interpretativa_binomio_ lengua_senas_lengua_hablada_2009.pdf [consulta: 11 de octubre de 2015].

Chaume Varela, Frederic (2013): "Panorámica de la investigación en traducción para el doblaje”, REVISTA $D E$ TRADUCTOLOGÍA, 17, 13-34. [En línea] http://www. trans.uma.es/trans_17/Trans17_013-034.pdf [consulta: 9 de diciembre de 2015].

Chaume Varela, Frederic (2005): "Los estándares de calidad y la recepción de la traducción audiovisual”, Puentes, 6, 5-12. [En línea] http://wdb.ugr.es/ greti/revista-puentes/ pub6/01-Frederic-Chaume.pdf [consulta: 9 de diciembre de 2015].

Metz, Christian, traducido por Taylor, Michael (1968): Film Language: A Semiotics of the Cinema. Chicago, University of Chicago Press.

Delisle, Jean (1993): La traduction raisonnée. Manuel d'initiation à la traduction professsionnelle de l'anglais vers le français, Adaptación española de Bastin, Georges L. Caracas, Universidad Central de Venezuela. 


\section{Lingzhi Nie}

Entreculturas 11 (2021) pp. 105-119

Real Academia Española (2014): Diccionario de la lengua española, 23. ${ }^{a}$ ed. Barcelona, Espasa.

Hurtado Albir, Amparo (2001): Traducción y traductología: Introducción a la traductología. Madrid, Ediciones Cátedra.

Martínez Sierra, Juan José (2004): Estudio descriptivo y discursivo de la traducción del humor en textos audiovisuales. El caso de los Simpson. Universidad Jaume I, Servicio de Publicaciones de la Universidad Jaume I. [En línea] http:// www.tdx.cat/bitstream/handle/10803/10566/martinez. pdf [consulta: 1 de noviembre de 2015].

Qian Shaochang (钱绍昌) (2000): “Yingshi fanyi-fanyi yuandi zhong yu lai yu zhongyao de lingyu (影视翻译一翻译园地中 愈来愈重要的领域)" [Traducción audiovisual--el dominio cada vez más importante en el ámbito de la traducción], Zhongguo fanyi (中国翻译), 1, 61-65.

Yang Heming (杨合鸣) (2015): Xinhua Zidian (新华字典) [Diccionario Xinhua]. Wuhan, Chongwen shuju (崇文书局).

Ye Jing (叶菁) (2012): “Shixi dianying 'yingxiong' de secai yuyan de Yingyong (试析电影《英雄》的色彩语言的运用)” [El análisis de los colores en la película Hero], Dianying wenxue (电影文学) (Movie Literature), 11, 142-143. [En línea] http://www.qb5200.com/content/2016-01-14/203559. html [consulta: 08/08/2017].

Zhang, Yimou (2004): Hero. Madrid, Sony Pict. H. Ent. \& Cia., S.R.C.

Zhang, Yimou (2009): Hero. Madrid, Blu-ray. 